\title{
A Symmetrical, Planar SOFC Design for NASA's High Specific Power Density Requirements
}

\author{
Thomas L. Cable \\ University of Toledo / NASA Glenn Research Center \\ Cleveland, OH 44135 \\ Stephen W. Sofie \\ QSS Group, Inc. / NASA Glenn Research Center \\ Cleveland, OH 44135
}

\begin{abstract}
Solid oxide fuel cell (SOFC) systems for aircraft applications require an order of magnitude increase in specific power density $(1.0 \mathrm{~kW} / \mathrm{kg})$ and long life. While significant research is underway to develop anode supported cells which operate at temperatures in the range of 650 $800^{\circ} \mathrm{C}$, concerns about $\mathrm{Cr}$-contamination from the metal interconnect may drive the operating temperature down further, to $750^{\circ} \mathrm{C}$ and lower. Higher temperatures, $900-1000^{\circ} \mathrm{C}$, are more favorable for SOFC stacks to achieve specific power densities of $1.0 \mathrm{~kW} / \mathrm{kg}$. Since metal interconnects are not practical at these high temperatures and can account for up to $75 \%$ of the weight of the stack, NASA is pursuing a design that uses a thin, $\mathrm{LaCrO}_{3}$-based ceramic interconnect that incorporates gas channels into the electrodes.

The bi-electrode supported cell (BSC) uses porous YSZ scaffolds, on either side of a $10-20 \mu \mathrm{m}$ electrolyte. The porous support regions are fabricated with graded porosity using the freeze-tape casting process which can be tailored for fuel and air flow. Removing gas channels from the interconnect simplifies the stack design and allows the ceramic interconnect to be kept thin, on the order of $50-100 \mu \mathrm{m}$. The YSZ electrode scaffolds are infiltrated with active electrode materials following the high temperature sintering step. The NASA-BSC is symmetrical and CTE matched, providing balanced stresses and favorable mechanical properties for vibration and thermal cycling.

\section{Introduction}

Solid oxide fuel cells (SOFCs) have tremendous commercial potential due to their high efficiency, high energy density, and flexible fuel capability, operating on both hydrogen and hydrocarbon based fuels. The materials and fabrication challenges of SOFCs have had a long development history and are well documented in several review articles [1,2]. The SOFC design is critical in the success of any new technology. The design impacts essentially every step of the development process: the options available for component fabrication, the maximum cell size, cell to interconnect contact and internal resistive losses, electrolyte thickness, cell performance, cell stresses and robustness, temperature gradients, fuel distribution, gas manifolds, seals, degradation mechanisms, manufacturing reproducibility and yields of parts, and ultimately all of these impact the economics. A poor initial cell design can lead down a road of continual short term fixes that can significantly limit the progress in scale-up while increasing the time and cost to commercialization.
\end{abstract}


The materials challenges for SOFCs are numerous and after 50 years of development the technology with the most demonstration experience is the Siemens Westinghouse (SW) tubular stack design. There are a number of reasons why the SW design is successful; the electrolyte is very thin, the ceramic interconnect, Ca-doped $\mathrm{LaCrO}_{3}$ (LCC), is very thin and stable, and the tubular design does not require seals, an issue very problematic in planar designs. However, despite the success of the SW system the large tubular design has a relatively low specific power density $(\mathrm{kW} / \mathrm{kg})$ that lead developers to begin looking at smaller, planar cell and stack designs, where cells could be stacked more compactly, to achieve higher specific power densities.

Planar design concepts were faced with two key initial challenges compared with the SW tubular technology; 1) they required high temperature seals and 2) they required that the LCC interconnect be much thicker and that it contain some pattern of channels for gas distribution. LCC interconnects initially required sintering in reducing environments at high temperatures to achieve full density [3] but years of materials research lead to sintering aids which allowed the LCC interconnect to be sintered in air atmospheres, to full density, at temperatures below $1500^{\circ} \mathrm{C}$. Unfortunately it was eventually discovered that the oxygen partial pressure gradient across the thick LCC plates created sealing and thermo-mechanical stress problems. Ultimately the high cost of the LCC raw materials and difficulties in manufacturing relatively complicated parts within precision tolerances, influenced developers to abandon the ceramic interconnects in favor of metallic interconnects.

Metal interconnects created new materials challenges; oxidation rates were too high at 900 $1000^{\circ} \mathrm{C}$ and the operating temperature was soon dropped to $850^{\circ} \mathrm{C}$. Also, metal interconnects had a higher coefficient of thermal expansion (CTE) than YSZ, making the YSZ/ metal interconnect seal difficult to maintain under thermal gradients and during thermal cycles. Even at the reduced temperature of $850^{\circ} \mathrm{C}$ it was discovered that the $\mathrm{Cr}_{2} \mathrm{O}_{3}$ scale, which protected the metal interconnect, was gradually volatilizing $\mathrm{Cr}$-based vapor species, which were then depositing at the cathode (4). In addition, the metal/cell contacts or repeat unit (RU) contact resistance became an increasing issue as the stack temperature was lowered. Curvature of the cells, when joined with the interconnects, can result in gaps of 100-200 microns (5), which must be bridged with conductive pastes (or other technique), normally deposited during manual stack assembly. It is also a common practice to deposit thin coatings on the metal interconnects, designed to reduce Cr-evolution and to improve the conductivity, composition or morphology of the oxide scale that is formed. With time at high temperatures and with thermal cycling, it is possible for the coatings to form micro cracks and to eventually spall, leading to higher contact resistance.

Recent studies indicate that $\mathrm{Cr}$-poisoning is so prevalent at $850^{\circ} \mathrm{C}$ that current planar stack development is being driven towards operating temperatures below $750^{\circ} \mathrm{C}$ for continuous operation with acceptable cathode degradation [6]. While reductions of cell temperature do alleviate several chemically induced degradation mechanisms, these reductions come at the cost of significantly reduced cell performance as shown in Figure 1. Reducing the temperature from $850^{\circ} \mathrm{C}$ to $700^{\circ} \mathrm{C}$ results in a drop in power density from $900 \mathrm{~mW}$ to $300 \mathrm{~mW}$, a $75 \%$ decrease [7]. While recent advances in materials and microstructure have improvement in low temperature operation, the power potential of SOFCs at higher temperature is being largely disregarded. 


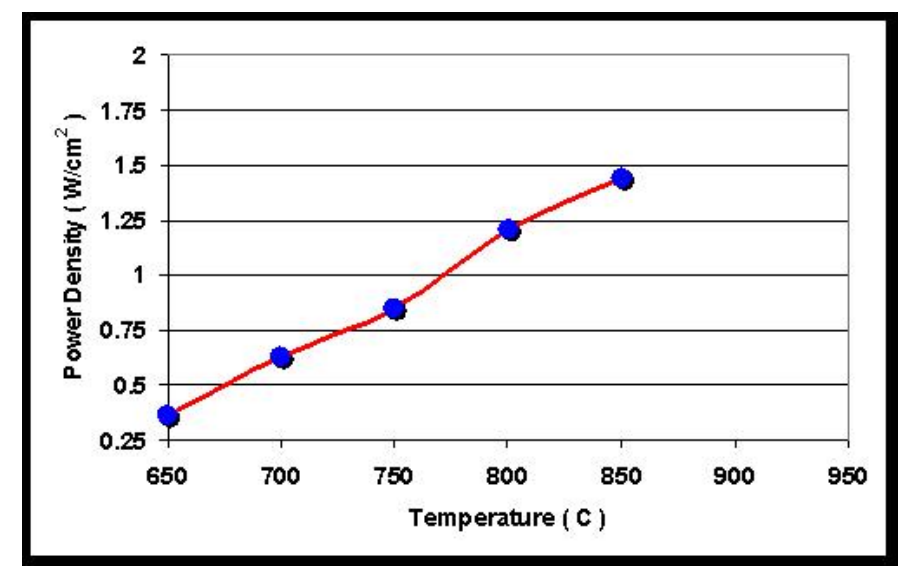

Figure 1: SOFC Button Cell Performance with temperature at $0.7 \mathrm{~V}$.

While small $\left(2-3 \mathrm{~cm}^{2}\right)$ anode supported cells (ASC) have shown impressive performance, as high as $2 \mathrm{~W} / \mathrm{cm}^{2}$ [8], the power losses for full sized cells, due to various polarizations, can exceed $40 \%$ in a multi-cell planar stack, reducing the actual performance per cell to $0.4-0.6 \mathrm{~W} / \mathrm{cm}^{2}(9)$. A number of problems contribute to this loss in power depending on the stack design; some are unavoidable such as gradients in temperature and fuel composition, but can be minimized by stack design. In spite of the long list of materials problems, significant progress is being made by the industrial teams in the DOE/SECA program. Some developers are beginning to report stack performance at $800^{\circ} \mathrm{C}$, approaching the DOE/SECA target of $0.2 \mathrm{~kW} / \mathrm{kg}$ for the stack [10]. While these levels of performance may be suitable for stationary power and ground transportation, the requirements for aeronautic and aerospace applications exceed specific power densities of $1.0 \mathrm{~kW} / \mathrm{kg}$, nearly five times the current technology levels (11). With metal interconnect content comprising greater than $75 \%$ of the stack weight, and current developers lowering temperatures to below $750 \mathrm{C}$, the challenge of increasing a cell designed for $0.2 \mathrm{~kW} / \mathrm{kg}$ to greater than $1.0 \mathrm{~kW} / \mathrm{kg}$ seemed insurmountable in the near future (12). The use of metallic interconnects, thus limiting the temperature, and the use of cambered anode supported cell, thus limiting sealing options and cell/interconnect conductivity has led NASA to evaluate alternative cell and stack concepts to meet the demanding requirements of high power, low weight/volume, and robust thermal $/$ mechanical performance.

\section{2. the Symmetrical, NASA Bi-supported Cell (BSC) Concept}

In developing a new cell concept NASA endeavored to address each of the key issues encountered by the state-of-the-art SOFC designs; the need to reduce the temperature, poisoning by $\mathrm{Cr}$, oxidation/reduction of the anode, the weight of the interconnect, cell/metal contact resistance and seals. To reach the highest possible power capabilities of SOFCs NASA chose to go to higher temperatures and to evaluate an all ceramic stack concept, using $\mathrm{LaCaCrO}_{3}$ (LCC) or other doped- $\mathrm{LaCrO}_{3}$ interconnects, rather than metal interconnects. The technical approach taken by the NASA design for each of the major hurdles discussed above is shown in Table 1. The key feature of the design concept is the symmetrical cell, which is made by supporting the thin electrolyte on both sides with a porous YSZ support structure, thus the name bi-supported cell or BSC. . 
Table 1: NASA BSC technical approach to major materials challenges

\begin{tabular}{|c|c|}
\hline $\begin{array}{l}\text { Materials Challenges of Anode Supported } \\
\text { Cells with Metal Interconnects }\end{array}$ & $\begin{array}{l}\text { NASA Glenn all ceramic design and fabrication } \\
\text { advantages }\end{array}$ \\
\hline $\begin{array}{l}\text { Developing a thin, supported, YSZ } \\
\text { electrolyte to compensate for reduced } \\
\text { operating temperature and avoiding } \\
\text { Ni-NiO oxidation/reduction }\end{array}$ & $\begin{array}{l}\text { Thin YSZ electrolyte is supported by } \\
\text { porous YSZ electrodes on both sides, } \\
\text { symmetrical and balanced stresses. All } \\
\text { ceramic allows high temperature } \\
\text { operation }\end{array}$ \\
\hline $\begin{array}{l}\text { Metal to Ceramic Seals perform well } \\
\text { at operating temperature but thermal } \\
\text { cycles a challenge, allowing about }\end{array}$ & $\begin{array}{l}\text { Integral YSZ seals are applied in the } \\
\text { green state, matched CTE with the thin } \\
\text { LCC interconnect and sintered with stack } \\
\text { to form hermetic seals }\end{array}$ \\
\hline $\begin{array}{l}\text { Contact resistance between the metal } \\
\text { interconnect/cell, design must } \\
\text { compensate for curvature of the cells. }\end{array}$ & $\begin{array}{l}\text { Cell and interconnect sintered together to } \\
\text { form a "unitized" repeat unit, electrode } \\
\text { infiltration ensures contact between } \\
\text { anode/cathode and LCC interconnect }\end{array}$ \\
\hline $\begin{array}{l}\text { Evolution of Cr-species from the } \\
\text { metal interconnect most likely } \\
\text { requires pretreatment and/or coatings }\end{array}$ & $\bullet \begin{array}{l}\text { LCC interconnect does not evolve Cr- } \\
\text { species, it is stable in SOFC operating } \\
\text { conditions. }\end{array}$ \\
\hline
\end{tabular}

The porous YSZ support structure (scaffold) has graded pores, so the gas channels or flow fields may be incorporated into the electrodes rather than the interconnect, thus significantly reducing the weight by allowing a thin, LCC interconnect. The graded porosity provides the smallest pores (1-5 microns) at the electrode/electrolyte interface, creating the maximum amount of active interfacial area or triple phase boundary (TPB) once the active electrodes are infiltrated. The continuous pore channels (tortuosity equivalent to 1 ) then increase in size to approximately 80100 microns in diameter and serve the role of gas flow fields for air and fuel. While there are numerous fabrication techniques commonly used in ceramic processing that can generate a graded porous structure (13), NASA has modified and developed a novel processing technique, based on freeze tape casting, to create previously unachievable pore morphologies in thin film ceramics. The thin electrolyte is deposited and sandwiched between two layers of identical green tape so it is balanced on either side with identical YSZ support structures or electrode scaffolds as shown in Figure 2. If the single cell is sintered at this stage it has the advantage of containing only YSZ, no other material, and of being symmetrical about the central electrolyte, which allows the part to sinter flat since the stresses are low and balanced equally on both sides of the thin electrolyte. 

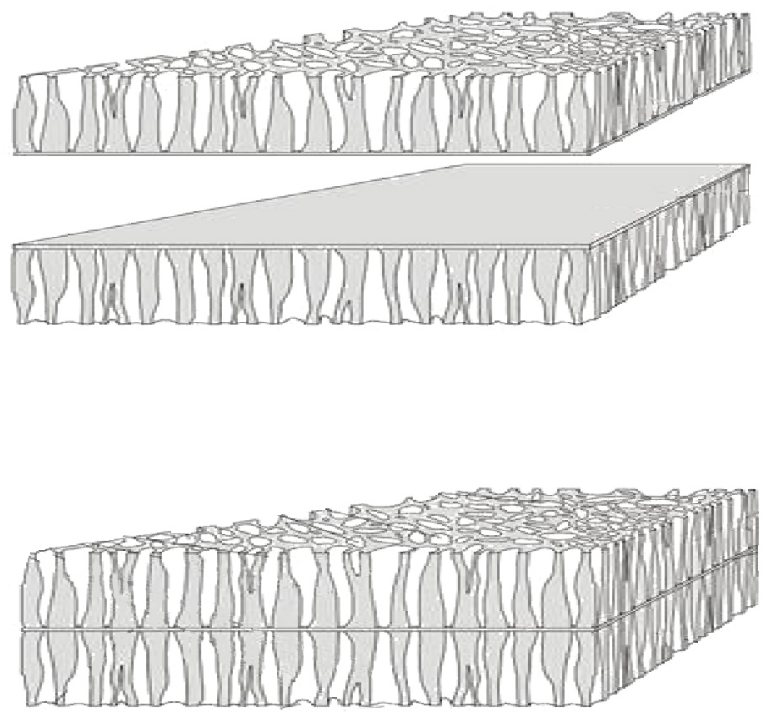

Figure 2: Thin YSZ electrolyte supported between two graded porous scaffolds.

Given the iso-material design of the cell and the ability to co-sinter the green unit as one assembly, the fabrication of the BSC repeat unit is relatively simple. A BSC stack is fabricated by coating one face of the cell with a thin layer of LCC, producing a repeat unit, followed by applying the thin YSZ edge seals as shown in Figure 3 with a simple cross-flow geometry. Multiple repeat units can be laminated in the green state to produce a multi-cell BSC stack. Deposition of the LCC is performed just like the electrolyte layer, by screen printing or air brushing over the large pores of the YSZ scaffold. One of the advantages of fabricating a number of cells into a stack using this method is that only the YSZ and LCC materials are fired in the high-temperature sintering step. Not only is it easier to optimize the sintering and shrinkage rates of only two discrete materials systems with similar thermal expansions, both materials are conducive to $1400^{\circ} \mathrm{C}$ firing schedules with negligible chemical interaction. 


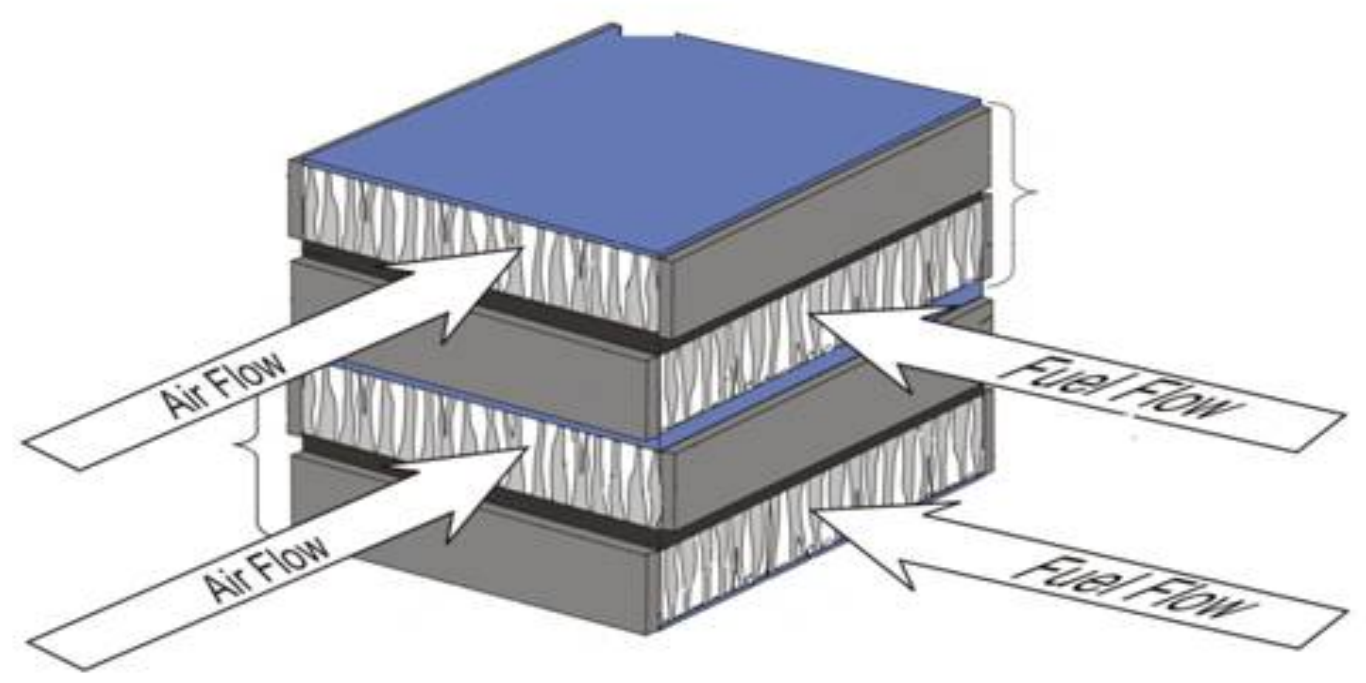

Figure 3: BSC cross-flow stack

The edge seals are made of YSZ and can be deposited in the green state using the same YSZ composition and particle size as the electrolyte. During sintering the three components of the multi-cell stack, the YSZ electrolyte, LCC interconnect, and YSZ edge-seals, shrink to high density (no open porosity) thus forming hermetic seals. Since the structural base of the cell has been prepared with a single high temperature processing step the "unitized", multi-cell stack can be leak tested and mechanically tested before further processing of electrode materials, which can minimize costs in scale-up and wasted electrode precursors. One of the most straightforward designs is the cross-flow design as is shown in Figure 3. Electrodes may be deposited by liquid or vapor chemistry techniques using the gas flow channels as a delivery vehicle. As the active electrode materials are deposited at the YSZ electrolyte/electrode interface, they also make intimate contact with the LCC interconnect, thus minimizing ohmic losses through the repeat unit.

If the BSC stack concept can be manufactured into the "unitized" stack as has been described, it could represent a substantial increase in specific power density. Comparing two repeat units (RU) with $10 \times 10 \mathrm{~cm}$ cells, considering all $100 \mathrm{~cm}^{2}$ area to be active, one RU made with metal interconnects and anode supported cells and the other RU using the BSC concept, both operating at $850^{\circ} \mathrm{C}$ with a moderate power density of $400 \mathrm{~mW} / \mathrm{cm}^{2}$, the ASC/metal interconnect RU would weigh approximately $143 \mathrm{~g}$ and the BSC RU would weigh approximately $29 \mathrm{~g}$. Using those assumptions the specific power density for the ASC $/$ metal interconnect RU is $0.28 \mathrm{~kW} / \mathrm{kg}$ and the BSC RU is $1.37 \mathrm{~kW} / \mathrm{kg}$ as shown in Figure 4. The power per volume is also greatly improved, being $1.3 \mathrm{~kW} / \mathrm{L}$ for the ASC and increasing to $9.3 \mathrm{~kW} / \mathrm{L}$ for the BSC. While there are optimistic assumptions made for this calculation it does however show the large potential in specific power that might be gained from altering the stack design, by and large by removing the heavy metal interconnects. Of added significance is the operating temperature, the ASC stack can not operate at $850^{\circ} \mathrm{C}$ with the heavy use of metals, while the BSC stack should be able to operate at higher temperatures, greater than $900^{\circ} \mathrm{C}$ if required, thus providing even higher power density. NASA 
GRC is in the process of evaluating, at the bench scale, the all ceramic, symmetrical BSC concept by fabricating cells, repeat units and eventually small stacks as discussed in detail below.

\begin{tabular}{|c|c|c|c|c|}
\hline Cell Type & $\begin{array}{c}\text { Cell } \\
\mathrm{t}(\mathrm{mm})\end{array}$ & $\begin{array}{c}\text { Repeat Unit } \\
\mathrm{t}(\mathrm{mm})\end{array}$ & $\begin{array}{c}\text { Repeat Unit } \\
\text { Wt. }(\mathrm{g})\end{array}$ & $\begin{array}{c}\text { Specific } \\
\text { P Density } \\
(\mathrm{kW} / \mathrm{kg})\end{array}$ \\
\hline ASC + Metal IC & 0.8 & 3.0 & 143 & 0.28 \\
\hline BSC & 0.62 & 0.67 & 29 & 1.37 \\
\hline
\end{tabular}

Based on single cell performance of $400 \mathrm{~mW} / \mathrm{cm}^{2}$

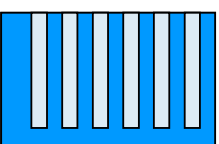

$1.37 \mathrm{~kW} / \mathrm{kg}$

BSC

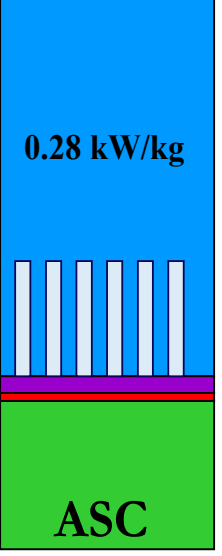

Figure 4: Comparison of BSC vs. ASC Specific Power Density

\section{Initial Fabrication Trials}

Initial fabrication of the BSC NASA took advantage of a new tape casting technique called freeze-tape casting, the details of which are the subject of another paper. In freeze-tape casting an aqueous or organic slip is cast across a freezing bed and micron size ice crystals start to form at the Mylar side of the tape and they gradually grow larger and larger towards the top as shown in Figure 5. The freezing process creates a natural gradient in porosity in the green tape and subsequently the ice crystals are removed by sublimation in a vacuum. Symmetrical cells were fabricated by taking two green parts cut from the same or similar freeze-tape cast substrates, depositing a thin electrolyte layer between the tapes, and laminating the tapes together with the small pores facing each other, forming the YSZ tri-layer. Symmetrical cells, with pinhole-free electrolytes, have been successfully fabricated as shown in Figure 6. The electrolyte layer can be formed by a number of ceramic processing techniques including air brushing, screen printing, and other green ceramic fabrication techniques. The interface between the electrolyte and the small pores of the porous electrode scaffold, due to the inherent green state porosity formed with freeze-tape casting, create an ideal rough interface for bonding, thus maximizing the length of the triple-point-boundary (TPB). 


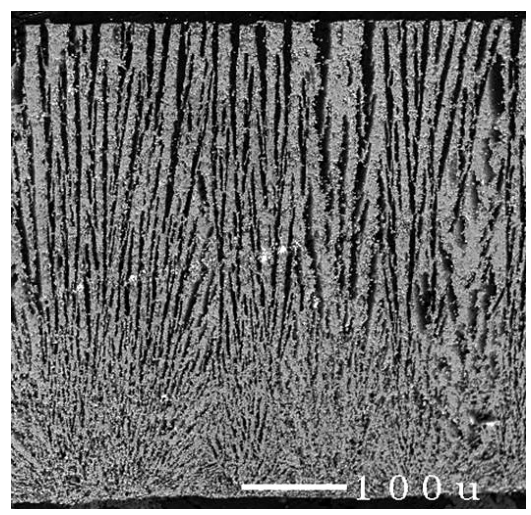

Figure 5: Single graded porous electrode scaffold

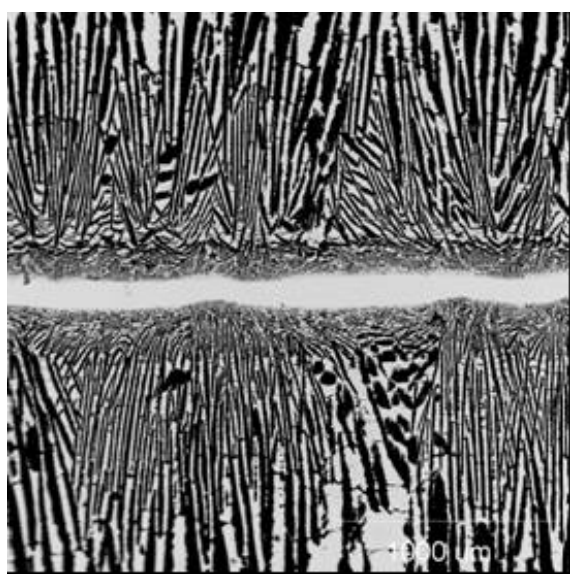

Figure 6: Cross section of sintered BSC prior to electrode infiltration

A strong benefit of the symmetrical cell design and iso-structural use of YSZ for the entire trilayer is the co-firing process. Uniform and equal densification of each opposing scaffold creates a uniform stress field with the electrolyte at the center. The result is a solid oxide fuel cell that sinters flat with no net curvature on either side of the electrolyte. Figure 7 illustrates the fabrication of a $19 \mathrm{~cm}$ diameter flat tri-layer fuel cell that was sintered free, without additional bisque firing steps or creep flattening procedures, and without the use of a weighted cover plate. This capability allows for potential scale-up to large diameters that can further increase the specific power density of an SOFC system. 


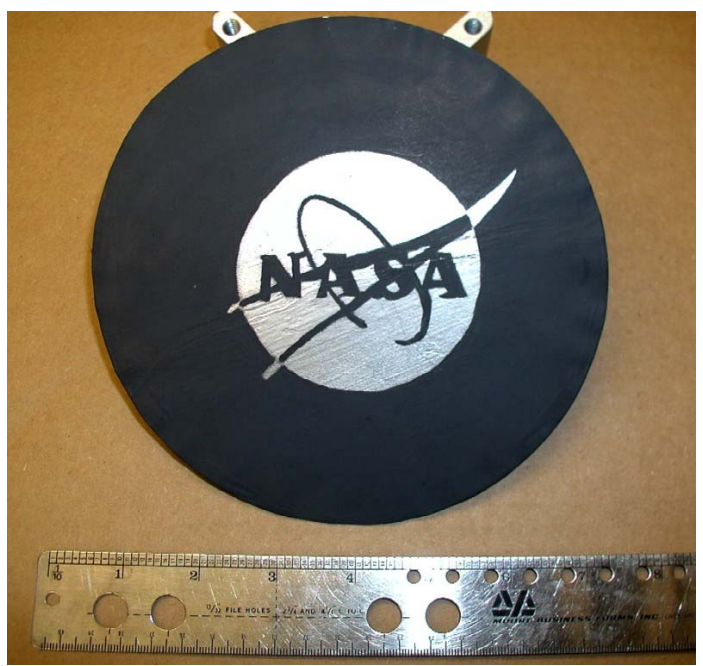

Figure 7: Large area $\left(285 \mathrm{~cm}^{2}\right.$ active area) YSZ-based BSC fabricated at $1400^{\circ} \mathrm{C}$

Initial electrode infiltration techniques have used Ni-nitrates or stoichiometric solutions of nitrates for the cathode. These nitrates were then infiltrated into the YSZ electrode scaffold, without the use of a vacuum, and were allowed to dry/solidify prior to heat treatment in both air and reducing atmospheres for decomposition of the nitrates into metals or metal oxides depending on the electrode. This infiltration procedure was performed multiple times on both the anode and cathode to achieve suitable electrode coverage as evaluated with SEM analysis. The final BSC is calcined at $600^{\circ} \mathrm{C}$ to ensure coalescence of materials from separate infiltration steps. Figure 8 is a high resolution scanning electron micrograph of porous YSZ electrode scaffolds infiltrated with active electrodes.
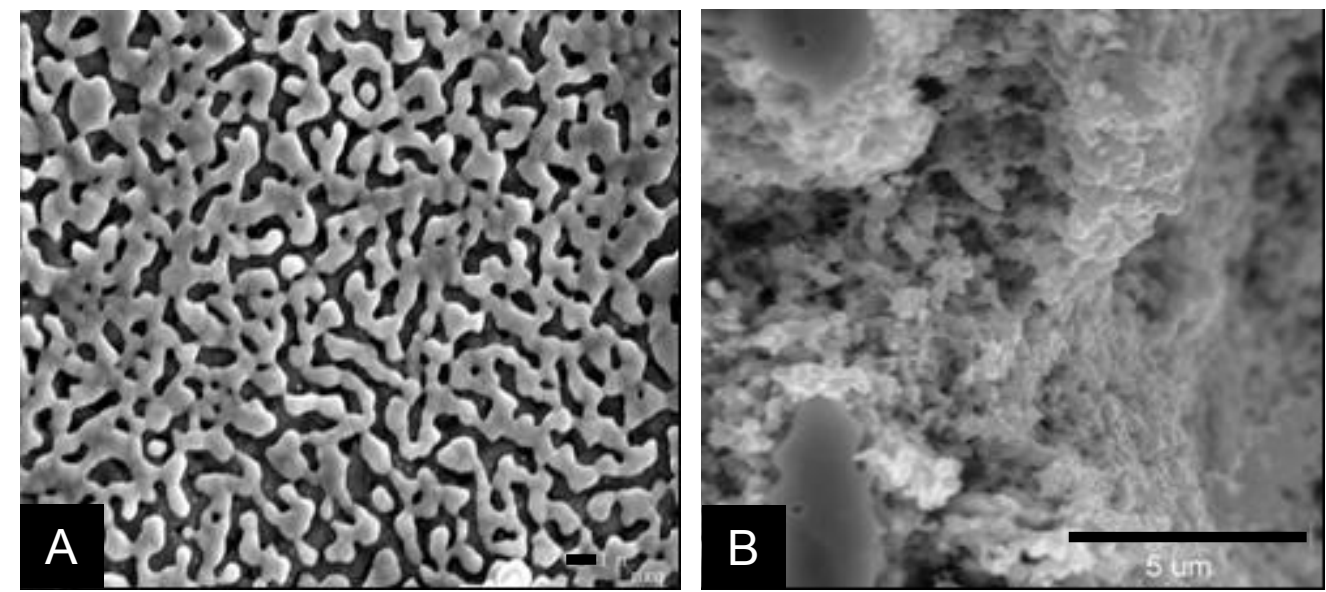

Figure 8: Infiltrated electrode scaffolds with continuous A: nickel metal anode (bar $=1 \mu \mathrm{m})$, and B: Lanthanum Strontium Ferrite LSF cathode $($ bar $=5 \mu \mathrm{m})$

To evaluate fabrication techniques for future development of repeat units and stacks, studies were initiated on LCC/YSZ bi-layers and YSZ/LCC/YSZ tri-layers to initiate matching of shrinkage curves and CTE. Custom LCC powders were synthesized and characterized at NASA to achieve sintering shrinkages and densities similar to that of $\mathrm{YSZ}$ at $1400^{\circ} \mathrm{C}$. Application of the thin LCC interconnect was performed in a similar way to the electrolyte layer, by screen printing, air brushing, or other technique, with the properties and viscosity of the ink/paint tailored for deposition over the large pores of the YSZ scaffold. 


\section{Discussion and Future Work}

In all SOFC designs there are fabrication and materials challenges to overcome, the major BSC challenges are listed in Table 2. The two most significant hurdles to this new design concept encompass the ability to effectively infiltrate stable electrodes at low weight percents as well as the issue of gas flow through the pore channels in a functioning cell and stack. The electrode infiltration may result in a multi-step process, although these processing steps may only require low temperature heat treatment, on the order of $400^{\circ} \mathrm{C}$. In particular, fabricating the nano/microstructured metallic anode and preventing the Ni-metal phase, or other metals, from sintering could prove to be a long-term hurdle but a potential opportunity for use of new highly conductive ceramics.

\section{Table 2. Technical Hurdles}

\begin{tabular}{|ll|}
\hline - & $\begin{array}{l}\text { Will the graded porosity of the porous YSZ electrode supports provide required fuel/air } \\
\text { feed without large back pressure or will they need additional channels }\end{array}$ \\
\hline$\bullet$ & Infiltration of the active electrodes into the porous gas channels from the edges \\
\hline$\bullet$ & Electrode impregnation may require multiple steps to provide enough electrode material \\
& for low ASR \\
\hline - & Can the Ni(m) be pinned into position to provide low sintering rate \\
\hline - & Demonstration of a multi-cell stack with hermetic edge seals and low ASR \\
\hline
\end{tabular}

Gas flow through the BSC channels, given the absence of line of sight or other simple pattern of channels interconnect designs, may present the largest challenge. Fuel and air back pressures could be very high due to the tortuous path created by YSZ support structures with graded porosity. Studies have been initiated at NASA GRC to quantify the permeability of the BSC flow fields fabricated by freeze-tape casting. A test rig has been fabricated and samples are in the process of being tested, with variations in electrode thickness and with steps taken to modify and improve the directionality of the flow channels. Results of this work will be discussed in a follow-up paper, which will also discuss electrochemical cell performance.

\section{Conclusions}

A novel, symmetrical cell architecture, the bi-electrode supported cell (BSC) and a compact stacking design has been developed to achieve the high specific power densities required by the aeronautics industry and for many other applications. Our calculations, described above, show that the BSC cell/stack design is capable of achieving $5 \mathrm{x}$ the power density and reaching the NASA target of $1.0 \mathrm{~kW} / \mathrm{kg}$, without requiring increases in power density at the cell level. The symmetric structure allows cells to be sintered at high temperature without shrinkage mismatches that can lead to curvature and/or residual stresses. Because fuel and air are manifolded through the thick scaffold electrodes, the interconnect does not require integral gas flow channels. Thus, interconnect thicknesses are greatly reduced, providing enormous increases in gravimetric and volumetric power density compared to existing anode-supported planar stack designs, making the BSC concept ideal for development of SOFC-based auxiliary power systems for jet aircraft. 
The BSC concept was designed with ceramics processing and scale-up in mind. All the fabrication processes are common in MLC processing and should be able to be scaled-up while maintaining low cost. Other anticipated benefits not discussed are robustness, allowing the stack to thermal cycle with less internal stresses and the flexibility of infiltrating non-traditional or multi-component electrode compositions by way of the liquid infiltration, while not affecting the CTE of the cell. As we proceed with development of aerospace APUs based on the BSC technology, there are a number of opportunities that will present themselves as the technology evolves. In addition to aircraft APUs, in the $440 \mathrm{~kW}$ range, the BSC design is amenable to applications where small, portable power systems are required, like those by the military in the $20-50 \mathrm{~W}$ range.

\section{Acknowledgment}

The authors would greatly like to acknowledge the contributions in fabrication to John Setlock and to the Program Manager, Dr. Serene Farmer.

\section{References}

1. N. Q. Minh, J. Am. Ceram. Soc., 76 [3] 563-88 (1993).

2. S. C. Singhal and K. Kendall, High Temperature Solid Oxide Fuel Cells: Fundamentals, Designs and Applications, Elsevier Science, January 1, 2004.

3. L. Groupp and H. U. Anderson, J. Am. Ceram. Soc., 57, 150 (1974).

4. E. Konysheva, H. Penkalla, E. Wessel, J. Mertens, U. Seeling, L. Singheiser and K. Hilpert, J. Electrochem. Soc., 153 (4) A765 (2006).

5. J. Lanutti, W. Li, OSU, DoE SECA-CTP Review Mtg., Sacramento, CA, Feb. 03.

6. Z. Yang, K. S. Weill, D. M. Paxton and J. W. Stevenson, J. Electrochem. Soc., 150 (9) A1188 (2003).

7. J. Stevenson, PNNL, National Space and Missile Materials Symposium, Seattle, Washington, June 21, 04.

8. J. W. Kim, A. V. Virkar, K. Z. Fung, K. Mehta and S. C. Singhal, J. Electrochem. Soc., 146 (1) 69-78 (1999).

9. S. Shaffer, Delphi, $6^{\text {th }}$ Annual SECA Workshop, Pacific Grove, CA, April, 18-21, 05.

10. A. Liang, www.netl.doe.gov/publications/proceedings/03/seca/Anita\%20Liang.pdf

11. L.M. Anderson and A. K. Misra, Symposium on Novel Vehicle Concepts and Emerging Technologies (Paper No.36), Brussels, Belgium, April 7-10, 03.

12. M. Stelter, A. Reinert, B. E. Mai and M. Kuznecov, J. Power Sources 154 (2006) 448.

13. S. Sofie and F. Dogan, J. Am. Ceram. Soc., 84 (7) 1459-69 (2001). 